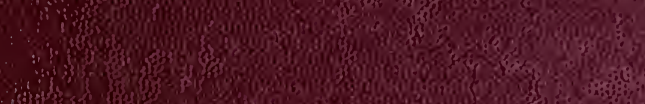
is

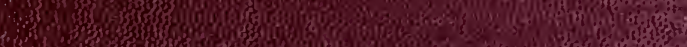

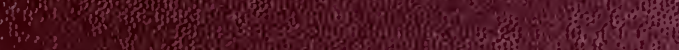

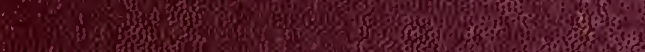

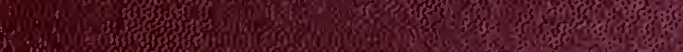

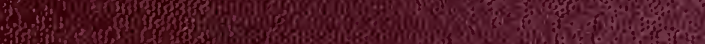
3

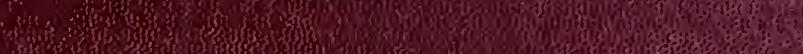
3. one

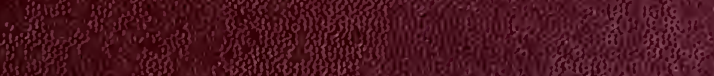
He 15.

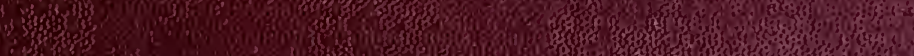
20.8 m and

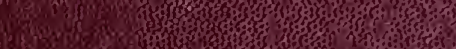

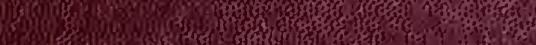

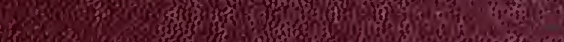

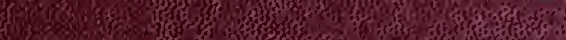

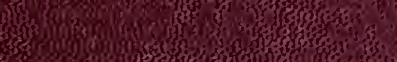

\title{
(3) 313
} 1. s.

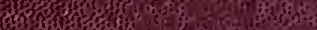
Hon m?

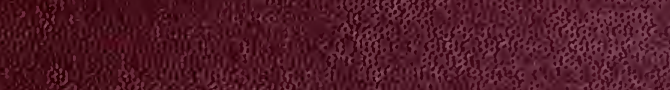

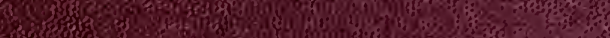
S. 4. m.

4 3.

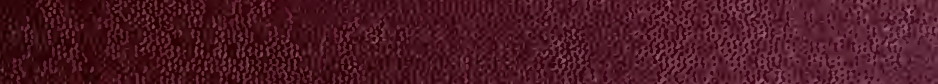

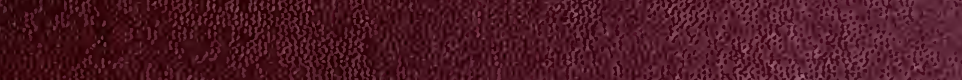
20.5 bis.6. (3) (1) is sisis a) 4. 3 m

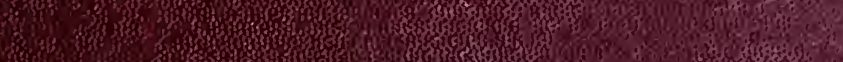
A

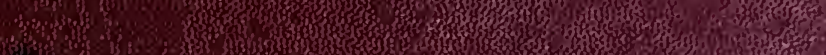
8. 



\section{Historic, archived document}

Do not assume content reflects current scientific knowledge, policies, or practices. 



\section{U. S. DEPARTMENT OF AGRICULTURE,} BUREAU OF ENTOMOLOGY-CIRCULAR NO. 138.

L. O. HOWARD, Entomologist and Chief of Bureau.

\section{THE OCCURRENCE OF BEE DISEASES IN THE UNITED STATES.}

\section{(PRELIMINARY REPORT.)}

BY

E. F. PHILliPs, Pн. D. In Charge of Bee Culture. 


\section{BLREAU OF ENTOMOLOFT.}

L. O. Howard, Entomologist and Chief of Bureau.

C. L. Marlatt, Entomologist and Acting Chief in Absence of Chief.

R. S. Clifton, Executive Assistant.

IV. F. Tastet, Chief Clerk.

F. H. Chittenden, in charge of truck crop and stored product insect inrestigations.

A. D. Hopkiss, in charge of forest insect investigations.

W. D. Hunter, in charge of southern field crop insect investigations.

F. M. WEBster, in charge of cereal and forage insect investigations.

A. L. Quantaxce, in charge of deciduous fruit insect inrestigations.

E. F. Phillips, in charge of bee culture.

D. M. Rogers, in charge of preventing spread of moths, field work.

Rolla P. Currie, in charge of editorial work.

MaBel Colcond, librarian.

\section{Investigations in Bee Culture.}

E. F. Phillips, in charge.

G. F. White, J. A. Nelsox, agents and experts. .

A. H. MCCRAY, apicultural assistant.

Pearl H. Garrisox, preparator.

H. A. Surface, collaborator for P'ennsylvamia.

II

[Cir. 1:88] 
CIRCULAR NO. 138.

\title{
United States Department of Agriculture,
}

\author{
BUREAU OF ENTOMOLOGY.
}

L. O. HOWARD, Entomologist and Chief of Bureau.

\section{THE OCCURRENCE OF BEE DISEASES IN THE UNITED STATES.}

\author{
(Preliminary Report.) \\ By E. F. Phillips, Ph. D., \\ In Charge of Bee Culture.
}

In conducting a campaign for the eradication or control of a pest it is of the highest importance that information be obtained concerning its location. For this reason one of the phases of the work on the brood diseases of bees in the Bureau of Entomology has been to learn where these diseases now occur in the United States. There has never before been an opportunity for such work, and the extent of disease has been largely a matter of estimate and conjecture. It is obvious that such data are of value not only in aiding present apiary inspection, but also in obtaining inspection where it is not now provided. These data are also to be used in the distribution of bulletins and other publications to the people who need them and in numerous other ways.

The object of the present publication is to present the data on this subject acquired by the bureau previous to March 1, 1911. It is not claimed that the work has been completed, for this is obviously not the case. The publication of this preliminary report is deemed advisable, so that those interested in the control of the brood diseases of bees may have an opportunity to make use of the present knowledge of the subject. It is hoped that bee keepers who have additional information will recognize the deficiencies of these records, and will aid in making them more complete by sending to this bureau samples of diseased brood for examination.

In asking bee keepers for data on the occurrence of these diseases it is found that some are unwilling to let it be known that they have disease in their apiaries. This, of course, should not be so, as it is no particular disgrace to have disease appear in the apiary. The disgrace comes in allowing it to remain. In appreciation of this feeling, however, the bureau makes it a policy not to announce the names of 
the men supplying the samples. The records are here made only by counties, and it is believed that no bee keeper will consider this a betrayal of confidence.

In making records it was necessary to consider a county as a unit. It is impracticable for the bureau to work with units smaller than counties. A county is recorded as containing disease when the first sample of diseased brood has been received from that county. In most cases, howerer, several samples have been receired from the counties recorded as having disease present. A considerable experience in the examination of infected apiaries indicates that it is usually safe to assume that disease is more widespread than is recognized by even the best bee keepers.

From the extent of the work it is obrious that most of these data were obtained by correspondence. No claim i- made that all of these counties have been visited. It did not seem adrisable to accept reports of the existence or nonexistence of disease, but to make positice records only on the receipt of a sample of diseased brood for examination. It frequently happens that letters are received stating that no disease has ever occurred in the county when samples of diseased brood have already been received in considerable numbers, and in some cases after personal examination has shown disease to be preralent. Furthermore, an infectious disease is often mistaken for chilled brood or so-called pickle brood, or vice versa. All samples recorded as containing disease were diagnosed in the hacteriological laboratory of the bureau. This work has been done by Dr. G. F. White, expert in bacteriology, and Mr. A. H. McCray, apicultural assistant. In all. about 1,800 samples have been examined.

It seems advisable to list certain counties as "suspected." From these counties satisfactory samples bare not been receired. A county is marked "suspected" when the bureau is informed of the presence of disease by an apiary inspector or by some beekeeper who is believed to be conversant with disease. The majority of such reports from bee keepers have not been accepted as satisfactory evidence eren for marking a county " suspected." In some cases such a record is made "suspected" if the result of an examination strongly suggests the presence of disease, but is not conclusive. In no are is a county marked as sumpected merely because of its proximity to known disease. If this were done the list would be greatly increased.

In case a bee keeper lives in one county and his post oflice is in another the sample received may in some cases be attributed to the wrong county. This source of error was not taken into consideration in the earlier work, but now the bureau asks the sender of a sample to give the town or township and county in which the apiary is located. Another possibility for error is in the changes in county houndaries. 
This is applicable especially in the Southern and Western States. Since in most cases several samples have been receired from each county giren as containing disease, it is believed that inaccuracies are few. The total number of counties in each State is taken from the Postal Guide of July, 1910.

For the information of bee keepers who may desire it, a brief statement is made concerning the apiary inspection in each State, where it is provided by law. Where possible, directions are given for reaching the inspector. In other cases this bureau can usually give the name of the present incumbent of the office. Copies of laws under which they work can be obtained from the inspectors of apiaries of the various States themselves.

The author desires to express his personal appreciation of the active cooperation which has been received from many apiary inspectors and experienced bee keeper's in all parts of the country. Without such cooperation the inrestigations of this bureau in bee culture could be of but small value.

\section{ALABAMA.}

[67 counties.]

No apiary inspection law.

AMERICAN FOUL BROOD.

Present.

Lowndes.

Nontgomery.

Suspected.

Baldwin.

Chambers.

Elmore.

Greene.

Tallapoosa.

Wilcox.

\section{ARIZONA.}

[13 counties.]

No apiary inspection. In 1899 a law was passed providing for apiary inspection to be supported by the beekeepers. For some time the Foul Brood Suppression Association of Maricopa County assumed this work.

AMERICAN FOUL BROOD.

Suspected.

Maricopa.

Yavapai.

[Cir. 138] 
ARKANSAS.

[75 counties.]

No apiary inspection law.

AMERICAN FOUL BROOD.

Present.

Chicot.

ECROPEAN FOIL BROOD.

Sispected.

Benton.

Franklin.

Phillips.

Washington.

\section{CALIFORNIA.}

[58 counties.]

County inspectors appointed by the county board of supervisors. There are sereral county ordinances in addition to the State law.

\section{Present.}

Colusa.

Fresno.

Inyo.

Kings.

Lassen.

Los Angeles.

Merced.

Riverside.

Sacramento.

San Bernardino.

San Diego.

Santa Barbara.

Tulare.

Ventura.

Suspected.

Butte.

Kern.

Madera.

Mariposa.

Monterey.

Orange.

San Benito.

San Joaquin.

San Luis Obispo.

Santa Clara.

Santa Cruz.

Siskiyou.

Stanislaus.

Sutter.

Yolo.

[Cir. 138]
EUROPEAX FOLL BROOD.

Present.

Fresno.

Suspected.

Imperial.

Kings.

Los Angeles.

Tulare. 
COLORADO.

[60 counties.]

County inspectors appointed by the county courts on petition of five resident bee keepers or on written application of the president or secretary of the State bee keepers' association.

AMERICAN FOUL BROOD.

Present.

Bent.

Boulder.

Delta.

Douglas.

La Plata.

Larimer.

Mesa.

Montezuma.

Montrose.

Otero.

Prowers.

Pueblo.

Weld.

Suspected.

Adams.

Arapahoe.

Denver.

Garfield.

Grand.

Huerfano.

Jefferson.

Routt.

\section{CONNECTICUT.}

[8 counties.]

Inspection under the supervision of the State entomologist, Connecticut Agricultural Experiment Station, New Haven.

AMERICAN FOUL BROOD.

Present.

Litchfield.

New Haven.

Suspected.

Fairfield.

Middlesex.

Tolland.

Windham.
EUROPEAN FOUL BROOD.

Present.

Fairfield.

Hartford.

Middlesex.

Tolland.

Windham.

No apiary inspection law.

DELAWARE.

[3 counties.]

DISTRICT OF COLUMBIA.

No apiary inspection law.

[Cir. 138] 


\section{FLORIDA.}

No apiary inspection law.

[47 counties.]

AMERICAN FOUL BROOD.

Present.

Escambia.

\section{GEORGIA.}

No apiary inspection law.

[146 counties.]

\section{HAWAII.}

[5 counties.]

The board of commissioners of agriculture and forestry, Honolulu, has issued rules and regulations pertaining to the importation and inspection of bees and honey in accordance with a Territorial law.

\section{IDAHO}

[23 counties.]

The State horticultural inspector is ex officio State bee inspector. AMERICAN FOLL BROOD.

Present.

Ada.

Bingham.

Canyon.

Fremont.

[Cir. 128] 


\section{ILIINOIS.}

[102 counties,]

No inspection under State supervision. The State bee keepers' association receives a grant allowing the appointment of an inspector of apiaries who can serve in an advisory capacity only.

AMERICAN FOUL BROOD.

Present.

Boone.

Bureau.

Carroll.

Champaign.

Clay.

Cook.

Dupage.

Edgar.

Fayette.

Greene.

Grundy.

Hancock.

Henry.

Kane.

Kankakee.

Knox.

Lake.

Lasalle.

Livingston.

Logan.

IcLean.

Macon.

Madison.

Peoria.

Putnam.

Saint Clair.

Sangamon.

Schuyler.

Stark.

Whiteside.

Will.

Winnebago.

Suspected.

Adams.

Bond.

Cass.

Dekalb.

Henderson.

Kendall.

Marshall.

Perry.

Pike.

Saline.

Stephenson.

White.
EUROPEAN FOUL BROOD.

Present.

Boone.

Calhoun.

Champaign.

Clay.

Cook.

Crawford.

Dekalb.

Douglas.

Fayette.

Grundy.

Jackson.

Jefferson.

Kankakee.

Lasalle.

IcHenry.

Macon.

Madison.

Marion.

Marshall.

Mason.

Montgomery.

Peoria.

Perry.

Piatt.

Rock Island.

Stark.

Tazewell.

Will.

Williamson.

Suspected.

Clinton.

Edgar.

Fulton.

Jasper.

Jo Daviess.

Pike.

Vermilion. 


\section{INDIANA.}

[92 counties.]

Inspection under the supervision of the State entomolngist, Indianapolis.

AMERICAN FOTL BROOI).

I'resent.

Allen.

Clinton.

Daviess.

Elkhart.

Grant.

Hamilton.

Jay.

Lake.

Marion.

Miami.

Newton.

Noble.

Porter.

Randolph.

Ripley.

sinspecter.

Hancock.

Jefferson.

Rush.

Tippecanoe.

Vanderburg.

Warren.

Warrick.

Wayne.

[Cir. 1:38]
E(TROPEAX FOLL BRUOI).

Iresent.

Cass.

Clay.

Daviess.

Fulton.

Huntington.

Jasper.

Jefferson.

Lake.

Laporte.

liami.

Newton.

like.

Porter.

Spencer.

Starke.

Yigo.

Warrick.

Suspected.

Benton.

Carroll.

Grant.

Marshall.

Pulaski.

Vanderburg.

IVarren.

White. 
IOWA.

[99 counties.]

An apiary inspection law has been passed but no appropriation was made and consequently no inspection has been done.

AMERICAN FOUL BROOD.

Present.

Allamakee.

Butler.

Carroll.

Clayton.

Clinton.

Des Moines.

Dickinson.

Fayette.

Fremont.

Hardin.

Linn.

Lyon.

Mills.

Pottawattamie.

Sac.

Story.

Woodbury.

Suspected.

Appanoose.

Buena Vista.

Cherokeé.

Davis.

Ida.

Marshall.

Monona.

Monroe.

Montgomery.

Page.

Plymouth.

Polk.

Scott.

Sioux.

Taylor.

Van Buren.

[Cir. 138]
EUROPEAN FOLL BROOD.

Present.

Guthrie.

Johnson.

Linn.

Muscatine.

Suspected.

Scott. 


\section{KANSAS.}

[105 counties.]

Inspection under the supervision of the entomologists of the University of Kansas, Lawrence, and of the Agricultural Experiment Station, Manhattan.

AMERICAN FOUL BROOD.

Present.

Crawford.

Douglas.

Ford.

Jewell.

Osborne.

Rice.

Shawnee.

Suspected.

Johnson.

Sumner.
ETROPE.IX FOLL BROOD.

Present.

Chase.

\section{KENTUCKY.}

[119 counties.]

An apiary inspection law has been passed but no appropriation was made and consequently no inspection has been done.

AMERICAN FOLL BROOD.

Present.

Boone.

Bracken.

Campbell.

Kenton.

Pendleton.
ELROPEAY FOLL BROOI).

Present.

Barren.

Bracken.

Fayette.

Hancock.

Logan.

McCracken.

Todd.

Trigg.

Suspected.

Bell.

Maclison.

\section{LOUISIANA.}

[60 counties.]

No apiary inspection law.

\section{MAINE.}

[16 counties.]

No apiary inspection law.

AMERICAN FOCL BROOI).

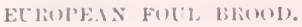

Present.

Hancock.

Present.

Penobsicot.

Sinsureted.

Androsengyin.

Hancock.

Waldo. 


\section{MARYLAND.}

[23 counties.]

No apiary inspection law.

AMERICAN FOUL BROOD.

Present.

Baltimore City.

EUROPEAN FOUL BROOD. Present.

Baltimore.

Garrett.

Suspected.

Allegany.

\section{MASSACHUSETTS.}

[14 counties.]

Inspection under the supervision of the assistant professor of beekeeping, Massachusetts Agricultural College, Amherst:

Present.

AMERICAN FOUL BROOD.

Bristol.

Hampden.

Middlesex.

Norfolk.

Worcester.

Suspected.

Essex.

Franklin.

Plymouth.

[Cir. 138]
EUROPEAN FOUL BROOD.

Present.

Berkshire.

Essex.

Hampden.

Middlesex.

Suffolk.

Worcester.

Suspected.

Hampshire.

Plymouth. 


\section{MICHIGAN.}

[83 counties.1]

Inspection under the supervision of the dairy and food commissioner, Lansing, Mich.

AMERICAN FOIL, BROOI).

Present.

Allegan.

Antrim.

Barry.

Benzie.

Berrien.

Branch.

Calhoun.

Clinton.

Eaton.

Genesee.

Gratiot.

Hillsdale.

Ingham.

Ionia.

Isabella.

Jackson.

Kalamazoo.

Kent.

Lapeer.

Lenawee.

Livingston.

Macomb.

Mason.

Mecosta.

Missaukee.

Montcalm.

Muskegon.

Oakland.

Oceana.

Osceola.

Ottawa.

Saginaw.

Saint Clair.

Shiawassee.

Tuscola.

Van Buren.

Washtenaw.

IVayne.

Suspected.

Charlevoix.

Grand Traverse.

Kalkaska.

Manistee.

Sanilac.
ETROPEAN FOTL BROOI).

Present.

Berrien.

Cass.

Manistee.

Mason.

Newaygo.

Saint Joseph.

Sanilac.

Van Buren.

Sispected.

Allegan.

Kalamazoo.

'The low.r peninsula, where all of the disenve occurs, so for as known, contuins cis counties.

[cir. $12 \mathrm{~s}]$ 


\section{MINNESOTA.}

[85 counties.]

Inspector appointed by the governor.

AMERICAN FOUL BROOD.

Present.

Benton.

Dakota.

Fillmore.

Hennepin.

Ramsey.

Wabasha.

Suspected.

Goodhue.

Washington.
EUROPEAN FOUL BROOD. Present.

Waseca.

Suspected.

Blue Earth.

\section{MISSISSIPPI.}

No apiary inspection law.

[79 counties.]

AMERICAN FOUL BROOD.

Suspected.

Benton.

Present.

EUROPEAN FOUL BROOD.

Washington.

Suspected.

Grenada.

\section{MISSOURI.}

[115 counties.]

Inspector appointed by the State board of agriculture.

\section{Present.}

AMERICAN FOUL BROOD.

Cape Girardeau.

Greene.

Jackson.

Jasper.

Schuyler.

Scotland.

Suspected.

Clark.

Clay.

Jefferson.

Mississippi.

Nodaway.

Pike.

Saint Charles.

Saint Louis.
EUROPEAN FOUL BROOD. Present.

Dade.

Jasper.

Lawrence.

Saint Charles.

Saint Louis.

Suspected.

Barton.

Cedar.

\section{MONTANA.}

[28 counties.]

No apiary inspection law.

[Cir. 138] 


\section{NEBRASKA}

[92 counties.]

County inspectors appointed by the governor. AMERICAN FOUL BROOD.

Present.

Adams.

Clay.

Douglas.

Fillmore.

Gage.

Garfield.

Greeley.

Hall.

Hamilton.

Lancaster.

Merrick.

Saline.

Saunders.

Seward.

York.

Suspected.

Butler.

Dakota.

Dixon.

Polk.

Scotts Bluff.

NEVADA.

[15 counties.]

No apiary inspection law.

AMERICAN FOUL BROOD.

Present.

Lyon.

NEW HAMPSHIRE.

No apiary inspection law.

[10 counties.]

AMERICAN FOUL BROOD.

Present.

Rockingham.

[Cir. 138] 
NEW JERSEY.

[21 counties.]

Inspection under the supervision of the State entomologist, New Brunswick.

Present.

AMERICAN FOUL BROOD.

Burlington.

Hunterdon.

Mercer.

Morris.

Suspected.

Gloucester.

Middlesex.

Salem.
EUROPEAN FOUL BROOD.

Present.

Burlington.

Hunterdon.

Mercer.

Middlesex.

Monmouth.

Morris.

Ocean.

Union.

Warren.

Suspected.

Essex.

\section{NEW MEXICO.}

\section{[26 counties.]}

Precinct inspectors appointed by board of county commissioners on petition of five resident bee keepers.

AMERICAN FOUL BROOD.

Present.

San Juan.

[Cir. 138] 


\section{NEW YORK.}

[61 counties.]

Inspection under supervision of commissioner of agriculture, Albany, N. Y.

AMERICAN FOLL BROOD.

Present.

Allegany.

Broome.

Cattaraugus.

Chautauqua.

Chemung.

Chenango.

Columbia.

Cortland.

Delaware.

Genesee.

Lewis.

New York.

Onondaga.

Schenectady.

Steuben.

Westchester.

Suspected.

Jefferson

Oneida.

Rockland.

Saint Lawrence.

Tioga.

Tompkins.

Wyoming.
EUROPEAN FOUL BROOD. Present.

Albany.

Broome.

Chemung.

Columbia.

Dutchess.

Erie.

Fulton.

Greene.

Herkimer.

Jefferson.

Montgomery.

Niagara.

Onondaga.

Oswego.

Otsego.

Rensselaer.

Saratoga.

Schenectady.

Schoharie.

Seneca.

Suffolk.

Tioga.

Tompkins.

Ulster.

Warren.

Washington.

Suspected.

Cayuga.

Delaware.

Lewis.

Ontario.

Orange.

NORTH CAROLINA.

[9s countie's.]

No apiary inspection law.

\section{NORTH DAKOTA.}

No apairy inspection law.

[46 counties.]

[Cir. 138] 
OHIO.

[88 counties.

Inspection under the supervision of the State entomologist, Columbus, Ohio. AMERICAN FOUL BROOD.

Present. EUROPEAN FOUL BROOD.

Allen.

Athens.

Auglaize.

Belmont.

Butler.

Champaign.

Cuyahoga.

Darke.

Defiance.

Delaware.

Franklin.

Hamilton.

Hardin.

Huron.

Marion.

Medina.

Miami.

Montgomery.

Ottawa.

Paulding.

Preble.

Seneca.

Union.

Van IVert.

Washington

Wayne.

Wood.

Suspected.

Carroll.

Clark.

Clinton.

Gallia.

Lucas.

Meigs.

Monroe.

Stark.

Tuscarawas.

[Cir. 138]

Present.

Ashland.

Ashtabula. 


\section{OKLAHOMA.}

\section{[76 counties.]}

No apiary inspection law.

IMERICAN FOLL BROOD.

Present.

Grant.

Kay.

Muskogee.

\section{OREGON.}

[34 counties.]

County inspectors appointed by the county court on petition of seven resident bee keepers. The law applies only to counties east of the Cascade Mountains.

AMERICAN FOUL BROOD.

Present.

Malheur.

Umatilla.

Washington.

Yamhill.

[Cir. 138] 


\section{PENNSYLVANIA.}

[67 counties.]

No apiary inspection law.

AMERICAN FOUL BROOD.

Present.

Bedford.

Bradford.

Bucks.

Butler.

Cambria.

Center.

Chester.

Delaware.

Elk.

Indiana.

McKean.

Montgomery.

Northumberland.

Potter.

Union.

Washington.

Wayne.

Suspected.

Berks.

Philadelphia.

Westmoreland.

Wyoming.
EUROPEAN FOUL BROOD.

Present.

Bedford.

Berks.

Blair.

Bradford.

Bucks.

Cambria.

Center.

Clarion.

Clearfield.

Clinton.

Columbia.

Crawford.

Erie.

Huntingdon.

Jefferson.

Lackawanna.

Lawrence.

Luzerne.

Lycoming.

Mercer.

Monroe.

Northumberland.

Philadelphia.

Schuylkill.

Susquehanna.

Venango.

Wayne.

Wyoming.

Suspected.

Adams.

Butler.

Carbon.

Chester.

Cumberland.

Franklin.

Fulton.

Lehigh.

Montour.

Perry.

Somerset.

Sullivan.

Tioga.

Westmoreland. 


\section{RHODE ISLAND.}

[5 counties.]

Inspection under the supervision of the State board of agriculture.

\section{SOUTH CAROLINA.}

[43 counties.]

No apiary inspection law.

\section{SOUTH DAKOTA}

[66 counties.]

District inspectors appointed by the governor.

AMERICAN FOUL BROOD.

Present.

Butte.

Clay.

Lawrence.

Yankton.

Suspected.

Bonhomme.

Hutchinson.

Lincoln.

Turner.

Union.

\section{TENNESSEE.}

[96 counties.]

No apiary inspection law.

AMERICAN FOUL BROOD.

Present.

Roane.

EUROPEAN FOUL BROOD,

Present.

[Cir. 138]

Shelby. 
OCCURRENCE OF BEE DISEASES IN THE UNITED STATES. 21

TEXAS.

[244 counties.]

Inspection under supervision of State entomologist, College Station.

AMERICAN FOUL BROOD.

Present.

Bexar.

Denton.

Ellis.

Frio.

Gonzales.

Limestone.

Navarro.

Uvalde.

Wilson.

Zavalla.

Suspected.

Bee.

Bosque.

Concho.

Coryell.

Delta.

Dallas.

Fannin.

Hayes.

Hunt.

Kaufman.

Live Oak.

McLennan.

Medina.

San Patricio.

Tarrant.

UTAH.

[27 counties.]

County inspectors appointed by county commissioners on petition of five resident bee keepers.

AMERICAN FOUL BROOD.

Present.

Emery.

Salt Lake.

Sanpete.

Sevier.

Utah.

Weber.

Suspected.

Carbon.

[Cir. 138] 


\section{VERMONT.}

[14 counties.]

Inspection under the supervision of the commissioner of agriculture.

AMERICAN FOUL BROOD.

Present.

Caledonia.

No apiary inspection law.

VIRGINIA.

[100 counties.]

EUROPEAN FOUI, BROOD. Present.

Frederick.

Highland.

Rockbridge.

Shenandoah.

WASHINGTON.

[ 38 counties.]

Former law providing for inspection repealed.

AMERICAN POLL BROOD.

Piesent.

King.

Yakima.

EUROPEAT FOUL BROOD.

Suspected.

Lew is.

Thurstoll.

\section{WEST VIRGINIA.}

No apiary inspection law.

[55 counties.]

AMERICAN FOUL BROOD.

Present.

Brooke.

[Cir. 138]
EUROPEAN FOUL BROOD.

Present.

Hampshire.

Jefferson.

Randolph.

Suspected.

Monongalia. 


\section{WISCONSIN.}

[71 counties.]

Inspector appointed by governor.

AMERICAN FOUL BROOD.

Present.

Crawford.

Dane.

Dodge.

Eau Claire.

Fond du Lac.

La Crosse.

Marathon.

Milwaukee.

Rock.

Suspected.

Clark.

Juneau.

Kewaunee.

Ozaukee.

Pierce.

Washington.

Waukesha.

Waushara

Winnebago.
Present.

EUROPEAN FOUL BROOD.

Columbia.

\section{WYOMING.}

[14 counties.]

No apiary inspection law.

Present.

AMERICAN FOUL BROOD.

Bighorn.

EXAMINATIONS OF SAMPLES OF DISEASED BROOD.

The Bureau of Entomology is prepared to assist in the diagnosis of disease in cases where the bee keeper is unable to tell whether or not disease is present or to determine which disease is in his apiary. Samples of brood comb about 5 inches square containing diseased or dead larvæ should be sent by mail in a strong wooden or tin box. The comb should not be wrapped in paper or cotton, but should be cut to fit the box closely. It is not possible to diagnose from empty combs, and no honey should be included in the sample, as it is valueless in diagnosis and will probably spoil the sample as well as other mail matter. The name of the sender must always appear on the package, and any available data should be sent in a separate letter. Never inclose a letter in the box with the sample.

During the summer of 1911 the bureau will on request send boxes in which samples may be mailed to bee keepers in counties not listed as containing disease.

[Cir. 138] 


\section{PUBLICATIONS OF THE DEPARTMENT OF AGRICULTURE ON BEE DISEASES.}

There are several other publications of the Bureau of Entomology of this department which deal with bee diseases. They may be obtained on request to the Editor and Chief of the Division of Publications, Department of Agriculture, and are the following:

Farmers' Bulletin No. 442, "The Treatment of Bee Diseases." By E. F. Phillips, Ph. D. 1911. 22 pp., 7 figs.

This publication gives briefly the symptoms of the various bee diseases, with directions for treatment.

Circular No. 94, "The Cause of American Foul Brood." By G. F. White, Ph. D. 1907. 4 pp.

This publication contains a brief account of the investigations which demonstrated for the first time the cause of one of the brood diseases of bees, American foul brood.

Bulletin No. 70, "Report of the Meeting of Inspectors of Apiaries, San Antonio, Tex., November 12, 1906." 1907. 79 pp., 1 pl.

Contains an account of the history of bee-disease investigations, the relationship of bacteria to bee diseases, and a discussion of treatment by various inspectors of apiaries and other practical bee keepers who are familiar with diseases of bees.

Bulletin No. 75, Part II, "Wax Moths and American Foul Brood." By F. F. Phillips, Ph. D. 1907. Pp. 19-22, 3 pls.

An account of the behavior of the two species of wax moths on combs containing Americall foul brood, showing that moths do not clean up the disease-carrying scales.

Bulletin No. 75, Part III, "Bee Diseases in Massachusetts." By Burton N. (iates. 1908. Pp. 23-32, map.

An account of the distribution of the brood diseases of becs in the State, with brief directions for controlling them.

Bulletin No. 75, Part IV, "The Relation of the Etiology (Cause) of Bee Diseases to the Treatment." By G. F. White, Ph. D. 1908. Pp. 33-42.

The necessity for a knowledge of the cause of bee diseases before rational treatment is possible is pointed out. The prescnt state of knowledge of the causes of disease is summarized.

Bulletin No. 98, "Historical Notes on the Causes of Bee Diseases." By E. F. Phillips, Ph. D., and G. F. White, Ph. D., M. D. (In press.)

A summary of the various investigations concerning the etiology (cause) of bec discases.

Technical Series No. 14, "The Bacteria of the Apiary, with Special Reference to Bee Diseases." By G. F. White, Ph. D. 1906. 50 pp.

A study of the bacteria present in both the healthy and the discased colony, with special reference to the diseascs of bees.

[Cir. 138] 
Table showing the prevalence of brood diseases in the United States.

\begin{tabular}{|c|c|c|c|c|c|c|c|}
\hline \multirow{2}{*}{ state. } & \multicolumn{7}{|c|}{ Number of counties- } \\
\hline & 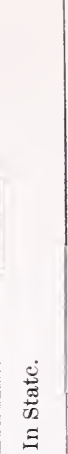 & 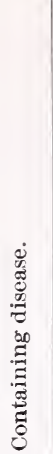 & 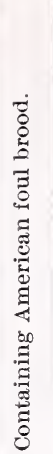 & 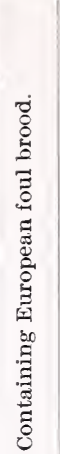 & 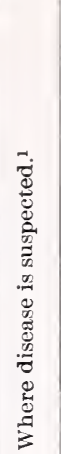 & 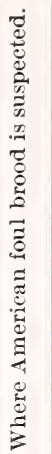 & 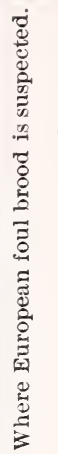 \\
\hline Alabama. & 67 & 2 & 2 & 0 & 6 & 6 & 0 \\
\hline A rizona . & 13 & 0 & 0 & 0 & 2 & 2 & 0 \\
\hline rkansas ... & 75 & 1 & 1 & 0 & 4 & 0 & 4 \\
\hline California... & 58 & 14 & 14 & 1 & 16 & 15 & 4 \\
\hline Colorado........ & 60 & 13 & 13 & 0 & 8 & 8 & 0 \\
\hline Connecticut.... & 8 & 7 & 2 & 5 & 0 & & 0 \\
\hline Delaware...... & 3 & 0 & 0 & 0 & 0 & 0 & 0 \\
\hline District of Columbia.... & & 0 & 0 & 0 & 0 & & 0 \\
\hline Florida .......... & 47 & 1 & 1 & 0 & 0 & 0 & 0 \\
\hline Georgia ...................... & 146 & 0 & 0 & 0 & 0 & 0 & 0 \\
\hline Hawaii ............ & 5 & 0 & 0 & 0 & 0 & & 0 \\
\hline Idaho............ & 23 & 4 & 4 & 0 & 0 & 0 & 0 \\
\hline Illinois............ & 102 & 48 & 32 & 29 & 14 & 12 & 7 \\
\hline Indiana........ & 92 & 27 & 15 & 17 & 11 & 8 & 8 \\
\hline Iowa.................... & 99 & 20 & 17 & 4 & 16 & 16 & 1 \\
\hline Kansas.......... & 105 & 8 & 7 & 1 & & & 0 \\
\hline Kentucky.............. & 119 & 12 & 5 & 8 & 2 & & 2 \\
\hline Louisiana....... & 60 & 0 & 0 & 0 . & 0 & & 0 \\
\hline Maine .......... & 16 & 2 & 1 & 1 & 2 & 0 & 3 \\
\hline Maryland........ & 23 & 3 & 1 & 2 & 1 & & 1 \\
\hline Massachusetts ... & 14 & 8 & 5 & 6 & 3 & 3 & 2 \\
\hline Michigan ............... & 283 & 43 & 38 & 8 & & & 2 \\
\hline Minnesota...... & 85 & 7 & 6 & 1 & 3 & & 1 \\
\hline Mississippi......... & 79 & 1 & 0 & 1 & 2 & 1 & 1 \\
\hline Missouri ........... & 115 & 11 & 6 & 5 & & & 2 \\
\hline Montana ........... & 28 & 0 & 0 & 0 & 0 & 0 & 0 \\
\hline Nebraska.......... & 92 & 15 & 15 & 0 & & & 0 \\
\hline Nevada......... & 15 & 1 & 1 & 0 & 0 & 0 & 0 \\
\hline New Hampshire............. & 10 & 1 & 1 & 0 & & & 0 \\
\hline New Jersey... & 21 & 9 & 4 & 9 & 3 & & 1 \\
\hline New Mexico............. & 26 & 1 & 1 & 0 & 0 & & 0 \\
\hline New York ........ & 61 & 37 & 16 & 26 & & & 5 \\
\hline North Carolina... & 98 & 0 & 0 & 0 & 0 & 0 & 0 \\
\hline North Dakota.............. & 46 & 0 & 0 & 0 & & & 0 \\
\hline Ohio ............. & 88 & 29 & 27 & 2 & 9 & 9 & 0 \\
\hline Oklahoma & 76 & 3 & 3 & 0 & & & 0 \\
\hline Oregon & 34 & 4 & 4 & 0 & 0 & & 0 \\
\hline 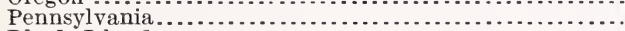 & 67 & 38 & 17 & 28 & 12 & & 14 \\
\hline Rhode Island................ & 5 & 0 & 0 & 0 & & & 0 \\
\hline South Carolina... & 43 & 0 & 0 & 0 & 0 & 0 & 0 \\
\hline 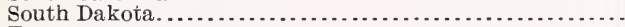 & 66 & 4 & 4 & 0 & 5 & 5 & 0 \\
\hline 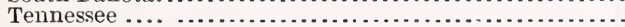 & 96 & 2 & 1 & 1 & 0 & 0 & 0 \\
\hline теxas & 244 & 10 & 10 & 0 & 15 & 15 & 0 \\
\hline Utah............. & 27 & 6 & 6 & 0 & 1 & 1 & 0 \\
\hline Vermont ...................... & 14 & 3 & 1 & 2 & 2 & 0 & 2 \\
\hline 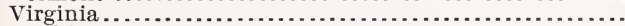 & 100 & 4 & 0 & $\overline{4}$ & 0 & 0 & 0 \\
\hline Washington & 38 & 2 & 2 & 0 & 2 & 0 & 2 \\
\hline West Virginia & 55 & 4 & 1 & 3 & 1 & 0 & 1 \\
\hline 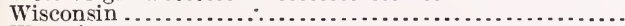 & 71 & 10 & 9 & 1 & 9 & 9 & 0 \\
\hline Wyoming..... & 14 & 1 & 1 & 0 & 0 & 0 & 0 \\
\hline Total ....... & 2,932 & 416 & 294 & 165 & 175 & 150 & 63 \\
\hline
\end{tabular}

1 When one disease is present and the other is suspected in a county, that county is not included in this column.

${ }^{2}$ The lower peninsula, where all of the disease occurs so far as known, contains 68 counties. [Cir. 138] 




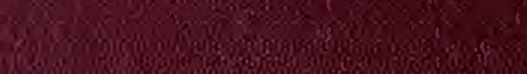

Wo

on

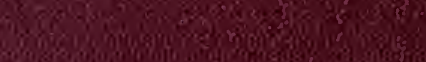

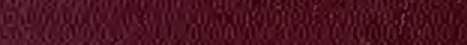

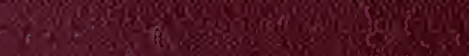

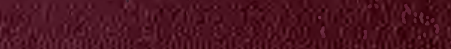

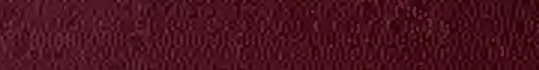

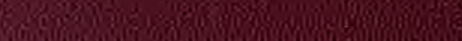

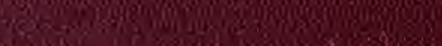

6.

arise

3.

Q

\%

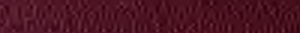

(1)

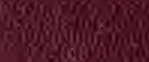

2.

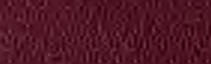

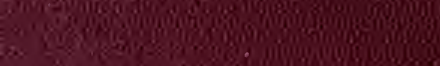

sil 30.6

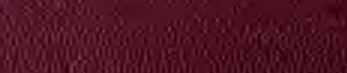

nowe

sels

Wrom

Po:singes

8000in:

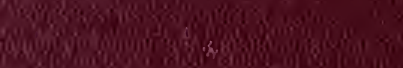

No.

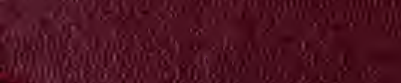

